\title{
POTENTIAL FOR SELF-DEFEATING BIOLOGICAL CONTROL? VARIATION IN HERBIVORE VULNERABILITY AMONG INVASIVE SPARTINA GENOTYPES
}

\author{
Dino Garcia-Rossi, ${ }^{1}$ Nathan Rank, ${ }^{2}$ and Donald R. Strong ${ }^{1,3,4}$ \\ ${ }^{1}$ Bodega Marine Laboratory, Box 247, Bodega Bay, California 94923 USA \\ ${ }^{2}$ Department of Biology, Sonoma State University, Rohnert Park, California 94928 USA \\ ${ }^{3}$ Section of Evolution and Ecology, University of California, Davis, California 95616 USA
}

\begin{abstract}
Invasive species can experience strong selection in their new environments. Some populations of invasive Spartina spp. cordgrass in Pacific estuaries have been separated from the specialist planthopper Prokelisia marginata for many generations while virtually no native populations, in estuaries of the Atlantic and Gulf coasts of North America, have experienced this separation. Contemplating the implications for biological control, we compared native cordgrass populations for resistance and tolerance to the planthopper with invasive ones that have been separated from the herbivore from many generations.

We found that plant genotypes varied more in their ability to resist and support planthoppers in a population that had been separated from the herbivore for many generations (in Willapa Bay, Washington, USA) than in one that had been consistently exposed to the herbivore (in San Francisco Bay, California, USA). In the former, some plant genotypes experienced $>50 \%$ shoot mortality while others experienced none. In contrast, in the latter no genotype experienced $>20 \%$ shoot mortality. Population growth rates of the herbivore paralleled this pattern among plant genotypes from the two populations. Extending previous observations, we found generally lower resistance and tolerance among six (nonnative) cordgrass populations that have been long-separated from the planthopper than in six (native) cordgrass populations that had been consistently exposed to it.

One Willapa Bay genotype of S. alterniflora was quite tolerant of the planthopper while lacking resistance; the high densities of the insect that grew on this genotype did it virtually no harm. Plant genotypes with this combination of traits are insidious to biological control. Initially they could contribute to control by fostering herbivores that harm vulnerable genotypes. However, as these tolerant plant genotypes increase in frequency, the effectiveness of biological control would decrease. Prokelisia marginata has recently been released in Willapa Bay for biological control of S. alterniflora. Our findings of tolerant but nonresistant genetic cordgrass variants suggest the need for complementary chemical and/ or mechanical control of less vulnerable genotypes. Attention to the frequency and nature of genetic variation in vulnerability to natural enemies in target species is germane to both the science and the practice of biological control.
\end{abstract}

Key words: biological control; herbivory; Prokelisia marginata; resistance; Spartina alterniflora; Spartina anglica; tolerance.

\section{INTRODUCTION}

Though little studied, rapid evolutionary change can occur during biological invasions (Vermeij 1996). Invasive plants are prime candidates for rapid evolution due to relaxed selection for defensive traits and different competitive regimes in their new environments (Thompson 1998). The natural variability of plants in resistance and tolerance (vulnerability) to herbivores is widespread (Strauss and Agrawal 1999). Hints of enemy-related evolution have been detected during invasions (Muldrew 1953, Burdon et al. 1981, Fenner 1983, Young 1986), and deeper understanding of these

Manuscript received 19 October 2001; revised 28 October 2002; accepted 13 March 2003; final version received 14 April 2003. Corresponding Editor: C. C. Horvitz.

${ }^{4}$ Corresponding author. E-mail: drstrong@ucdavis.edu processes is crucial to safe and effective biocontrol (Barrett 1992, Clement 1994, McEvoy 1996, Gould et al. 1997, Strong and Pemberton 2000).

Relaxation of selection by release from herbivory could lead to an intermediate period of high variance in vulnerability among invasive plants (Burdon et al. 1981). Were an effective biological control agent introduced during this intermediate period, invulnerable genotypes could proliferate at the expense of vulnerable ones eliminated by the biocontrol agent. Ultimately this could create a target population upon which the natural enemy had little effect. Without complementary control by other means of the less vulnerable genotypes, natural selection could lead to self-defeating biological control. Though a classic scenario of evolution caused by natural enemies, such ideas have not been much explored in biological control; they 
should also be of high interest to the study of invasive species (Keane and Crawley 2002). Cordgrasses are invaders of Pacific estuaries, and our earlier work suggested that they could provide an example of this scenario.

Invasive populations of Spartina alterniflora (and $S$. anglica) that have not recently (or ever) been in contact with the specialist planthopper Prokelisia marginata appeared to have lower mean resistance and tolerance to herbivory by this planthopper than native populations that have not experienced this separation (Daehler and Strong 1997, Wu et al. 1999). The first objective of this study was to examine the effects of contact history on mean vulnerability to the planthopper of cordgrass populations. The second, more difficult objective was to examine variation in vulnerability within populations following separation of the plant from the herbivore. The ideal experimental design for exploring this issue was precluded when authorities erroneously ordered the destruction of some strains of cordgrass. Nevertheless, we at least were able to compare a population of $S$. alterniflora that had been released from herbivory about 100 years ago (when introduced to Willapa Bay, Washington, USA) with another that has never been separated from this herbivore (introduced to San Francisco Bay, California, USA, 25 years ago). Both of these cordgrass populations are outside $S$. alterniflora's native range (Daehler and Strong 1996); however, the planthopper was present in San Francisco Bay, where it had existed upon native California cordgrass, S. foliosa, previously (Denno et al. 1996).

Spartina anglica was created in the 19th century in England by hybridization between $S$. alterniflora introduced from North America and S. maritima native to Europe (Raybould 1991). All specialist insect herbivores of Spartina are native to Atlantic and Gulf coast estuaries of North America and absent from Europe. The most common and abundant herbivores are planthoppers in the genus Prokelisia spp. (Heady and Wilson 1990, Denno et al. 1996). Other specialists include the stem-boring cecidomyid fly Calamomyia alterniflorae (Gagné 1981) and the scale insect Haliaspis sp. (Strong et al. 1984, Liu and Howell 1994). Thus, S. anglica is made up of the $S$. maritima genome, which has never experienced $P$. marginata, and that of $S$. alterniflora, which evolved with this herbivore. To our knowledge, no population of $S$. anglica has ever been subject to herbivory by $P$. marginata, although the $S$. alterniflora part of its hybrid genome derives from a long-established interaction with the planthopper. $S$. anglica in general and $S$. alterniflora from Willapa Bay have been separated from $P$. marginata for many generations, and we refer to them as "long-separated" cordgrasses.

Spartina anglica was deliberately introduced to estuaries of Britain, Europe, China, and New Zealand for sheep grazing and to Australia, Tasmania, and Puget Sound, Washington, for stabilizing soft intertidal sediments. S. anglica is now considered a serious pest of salt marshes worldwide and has been found to be vulnerable to $P$. marginata in greenhouse tests (Wu et al. 1999). S. alterniflora is native to the Atlantic and Gulf coasts of North America where $P$. marginata is a ubiquitous herbivore of this cordgrass in native areas. $P$. marginata has been introduced to Willapa Bay as a biological control agent of S. alterniflora (Grevstad et al. 2003).

In San Francisco Bay, Spartina foliosa (native California cordgrass) has a long-established interaction with P. marginata (Denno et al. 1996). S. alterniflora became a second host when it was introduced to San Francisco Bay 25 years ago (Faber 2002). In Pacific estuaries, the northern limit of native Spartina spp. and Prokelisia spp. is Bodega Bay, California. S. alterniflora was introduced to Willapa Bay $900 \mathrm{~km}$ to the north $\sim 100$ years ago, without $P$. marginata or other specialized herbivores (Daehler and Strong 1997). Thus, the cordgrass populations in this study that have been long-separated from herbivory are S. anglica and S. alterniflora from Willapa Bay. Those that have never been separated from the planthopper include all populations of $S$. alterniflora from the native range on the Atlantic and Gulf coasts and that from San Francisco Bay.

Spartina alterniflora is a perennial, wind-pollinated, obligately outcrossing grass. Seed set is low in the invasive populations in San Francisco Bay and Willapa Bay, probably owing to inbreeding depression and the paucity of wind-borne pollen available to the invader (Daehler 1999). Study of cordgrass vulnerability to $P$. marginata presents the challenges common to understanding effects of herbivores that feed in aggregations, such as many species of Homoptera, upon long-lived plants. P. marginata is tiny and feeds upon sap from the vascular system. The fluid removed by each insect is relatively small and difficult to quantify (Walling 2000). Numbers upon the plant build through a series of generations over the growing season. Wounds due to oviposition as well sap removed by insect feeding are harmful to the plant. (There is no evidence that plant diseases are transmitted by these planthoppers [Davis et al. 2002].) Cumulative plant damage caused by the herbivore colony over the course of the growing season is a quantity that integrates the effects of the insects and a parameter that is meaningful to the study of biological control and to understanding evolution of this insect-plant interaction. We measured effects of $P$. marginata upon vegetative growth and survival but not on seed set.

Apropos to the questions of release from herbivory and selection imposed by biological control, we performed a series of greenhouse assays. We first asked how contact history between cordgrass populations and the planthopper affected the suitability of host plants for insects (resistance). Second, we asked how contact history affected the ability of cordgrass to withstand the herbivore (tolerance). Finally, we asked if release 
TABLE 1. Experimental objectives, cordgrass accessions (Greek letters), contact history (footnotes), and sample sizes (in parentheses) in this study.

\begin{tabular}{|c|c|c|c|}
\hline \multirow{2}{*}{$\begin{array}{l}\text { Experi- } \\
\text { ment }\end{array}$} & \multirow[b]{2}{*}{ Objective } & \multicolumn{2}{|c|}{$\begin{array}{l}\text { Cordgrass (Prokelisia marginata) } \\
\text { accessions, contact history }\end{array}$} \\
\hline & & Long-separated $\dagger+$ & Never separated $\S \|$ \\
\hline A & resistance, nymphal development & $\varepsilon \dagger(9), \zeta \ddagger(3), \eta \ddagger(3), \theta \ddagger(7)$ & $\beta(2), ı \S(2), \kappa \S(2), \lambda \S(2), \mu \S$ \\
\hline B & resistance, nymphal emergence & $\gamma \S(37)$ & $\delta \S(36)$ \\
\hline $\mathrm{C}$ & resistance, oviposition rate & $\alpha \dagger(4)$ & $\beta \|(4)$ \\
\hline $\mathrm{D}$ & $\begin{array}{l}\text { tolerance: plant biomass, shoot length, } \\
\text { shoot number, leaf number, mortality }\end{array}$ & $\gamma(24), \zeta(24), \eta(24), \theta(24)$ & $\delta(24)$ \\
\hline $\mathrm{D}$ & planthopper population growth & $\gamma(24), \zeta(24), \eta(24), \theta(24)$ & $\delta(24)$ \\
\hline $\mathrm{E}$ & $\begin{array}{l}\text { intrapopulation variation, plant bio- } \\
\text { mass and shoot mortality }\end{array}$ & $\alpha(8)$ & $\beta(9)$ \\
\hline $\mathrm{E}$ & planthopper population growth & $\alpha(8)$ & $\beta(9)$ \\
\hline $\mathrm{E}$ & $\begin{array}{l}\text { tolerance, plant biomass, and shoot } \\
\text { mortality }\end{array}$ & $\alpha(8)$ & $\beta(9)$ \\
\hline
\end{tabular}

Notes: Greek letters are cordgrass accessions, followed by site, species, plant material, and collection date: $\alpha=$ Willapa Bay, Washington (USA), Spartina alterniflora, vegetative fragment, August 1998; $\beta$ = San Francisco Bay, California (USA), S. alterniflora, vegetative fragment, August 1998; $\gamma=$ Willapa Bay, S. alterniflora, seed, October 1998; $\delta$ = Virginia Beach, Virginia (USA), S. alterniflora, seed, February 1999; $\varepsilon=$ Willapa Bay, S. alterniflora, vegetative fragment, June $1998 ; \zeta=$ Victoria, Australia, Spartina anglica, seed, March 1999; $\eta=$ Tasmania, Australia, S. anglica, seed, March 1999; $\theta=$ Puget Sound, Washington (USA), S. anglica, vegetative fragment, October 1998; ı = Sapelo Island, Georgia (USA), S. alterniflora, vegetative fragment, June 1999; $\kappa=$ Eastern Shore, Maryland (USA), S. alterniflora, vegetative fragment, June 1999; $\lambda=$ Providence, Rhode Island (USA), S. alterniflora, vegetative fragment, June 1999; $\mu=$ Jensen Beach, Florida (USA), $S$. alterniflora, vegetative fragment, June 1998. We collected all accessions with the exception of accession 4, which we purchased from Environmental Concern, St. Michaels, Maryland, USA. For a description of contact histories, see the Introduction.

$\dagger$ Spartina alterniflora was introduced to Willapa Bay ca. 100 years ago without Prokelisia marginata or any other specialist herbivore.

\# Spartina anglica is a hybrid species, never in contact with $P$. marginata. The pollen parent was $S$. alterniflora, which had primeval association with $P$. marginata; the seed parent was $S$. maritime, with no contact with $P$. marginata.

$\S$ Native range, always in contact with the planthopper.

$\|$ Introduced, always in contact with planthopper.

from the herbivore could affect within-population variance of vulnerability to it. Because the third objective is novel while the first two attempt to extend and amplify previous results (Daehler and Strong 1997, Wu et al. 1999), we emphasize the third objective in the Abstract and Discussion.

\section{Materials AND Methods}

We contrasted six populations of Spartina alterniflora and S. anglica that have been long-separated from the specialist herbivore Prokelisia marginata with six native populations of $S$. alterniflora that have never been separated from this herbivore. We examined four insect traits (oviposition rate, nymphal emergence from eggs, rate of nymphal development to adults, and planthopper population growth rate) and five plant traits (biomass, shoot length, shoot number and mortality, leaf number, and plant mortality). Table 1 gives the experimental objectives, contact history of cordgrass accessions, insect and plant traits, plant material (different genets from seed or vegetative fragments), and sample sizes. The insect and plant material available for experiments were logistically constrained by a combination of regulations and erroneous administrative decisions that led to the destruction of some strains of Spartina spp. that we had in cultivation for this study.
To understand resistance independently of tolerance, we measured oviposition, nymphal emergence, and nymphal development to adults at planthopper densities so low that the herbivore did not degrade the plant (experiments A, B, and C, Table 1). The most sensitive indicator of $P$. marginata damage to Spartina $\mathrm{sp}$. is distinctive chlorosis of leaf tips, and we determined from a calibration experiment that the density of insects used in the resistance experiments was below that causing this kind of chlorosis. Tolerance was studied relatively, as the plant trait value when grown with $P$. marginata divided by the trait value of replicate plants grown without it (experiments D and E). In nature, planthopper colonies go through series of generations during the growing season, and we tested the increase in planthopper density as a measure of the way cordgrass and $P$. marginata interact (experiments $\mathrm{D}$ and $\mathrm{E}$ ). This allows planthoppers to increase to densities that can harm cordgrass, which means that it measures a combination of resistance and tolerance. Planthopper density was divided by stem length, to adjust for different plant sizes among cordgrass populations.

To study within-population variance (experiment E), we focused upon a pair of invasive cordgrass populations with contrasting contact histories, the Willapa Bay population, which has grown without the herbivore 
for more than 100 years, and the San Francisco Bay population, which has always lived with the herbivore. We propose that these comparisons are pertinent to the effect that planthoppers could have in a biological control program.

\section{Cordgrass culture}

All experiments were conducted in the greenhouse at the Bodega Marine Laboratory, Bodega Bay. Prokelisia marginata were collected from San Francisco Bay (Daehler and Strong 1997). Mean greenhouse temperature during March-August was $23^{\circ} \mathrm{C}$ by day and $12^{\circ} \mathrm{C}$ by night. All plants were grown $\left(60^{\circ} \mathrm{C}\right.$ for $\left.24 \mathrm{~h}\right)$ in a pasteurized mix of $25 \%$ Bodega Bay mud and $75 \%$ coarse vermiculite by volume. Seedlings were grown in $500-\mathrm{mL}$ plastic pots and vegetative propagules in 2$\mathrm{L}$ pots; both were fertilized every $3 \mathrm{wk}$ with $0.25 \mathrm{~g}$ of Plantex 20-20-20 (Plant Products, Ontario, Canada). Pots were placed in plastic trays $30 \times 45 \times 13 \mathrm{~cm}$ and watered regularly with $33 \%$ seawater. Species identity of San Francisco Bay S. alterniflora (experiments A, $\mathrm{C}$, and E) was verified with random amplified polymorphic DNA (RAPD) markers (Ayres et al. 1999). Five hundred seedlings from each accession were planted in June 1999 (experiments B, C, and D).

Root masses and attached stems that grew from each seedling were broken apart, potted separately, and propagated (February-April 2000) to create four replicates (pots); these were grown with artificial light (16 h:9 h light:dark) supplementing natural light for $10 \mathrm{wk}$ (May-June 2000), except during the experiment (9 June-21 June 2000; experiments A, B, and C), when they were grown under natural light alone. For withinpopulation variation (experiment E), we collected eight vegetative fragments (genotypes), one each from of a number of widely separated clumps of Spartina alterniflora from Willapa Bay (eight clumps) and San Francisco Bay (nine clumps) and propagated each genotype into eight replicates (May-September 1997). We chose pairs of replicates with the same number of shoots and of roughly equal size for random assignment to each of the two planthopper treatment combinations (high density and very low density).

\section{Suitability of host plants for insects, resistance}

To study nymphal development (experiment A), we began when each plant had three leaves on each of three shoots (nine leaves total). We placed three second instar planthopper nymphs into a plastic tube on the third youngest leaf on each plant, one tube per plant. We used 12 tubes (plants), three insects per tube. We recorded mortality and development to adults every other day. A treatment combination of moist filter paper only was a no-food control. Planthopper sex ratio was $1: 1$ at the end of the experiment, when the nymphs had matured. The dependent variable was the proportion of insects surviving to adulthood by the end of the 12th day. Before analysis, we obtained the total number of insects per genotype (sum of two plants) within each block and then calculated clonal means and finally calculated means for each population origin. A $t$ test of the a priori hypothesis contrasted the cordgrasses by contact history. To study nymphal emergence (experiment B) we counted the number of first instar nymphs emerging from eggs, $47 \mathrm{~d}$ after introduction of gravid females and males into tubes. To study insect oviposition rate (experiment $\mathrm{C}$ ), we counted the number of eggs laid. These experiments were begun on 24 June 1999, when one male and one gravid female planthopper were placed into each tube. Both the tubes and the adult planthoppers were removed after $2 \mathrm{wk}$, a time sufficient for mating and oviposition, as confirmed by distinctive oviposition scars in the leaves. To account for mean/variance relationships, we used a $t$ test of logtransformed number of nymphs (experiment B) and number of eggs (experiment B) and analysis.

\section{Tolerance of plants to herbivory}

We measured the effect of the planthopper on relative performance of cordgrass as the ratio of the value of plants grown with the planthopper to that of plants grown without the planthopper. The experiment began with all plants at $\sim 0.4 \mathrm{~g}$ dry mass (estimated from regression between shoot length and biomass; D. Garcia-Rossi, unpublished data). Experiment D was performed February-May 2000 in 12 screen cages, 30 $\times 45 \times 122 \mathrm{~cm}$. Each cage contained two seedlings of the same size from each cordgrass origin. Prior to addition of planthoppers, seedlings were trimmed to three shoots per plant, mean height $7.8 \mathrm{~cm}$, and three fully extended leaves per shoot. Half of the cages received two gravid female and two male planthoppers per plant, the other half received no planthoppers. The planthoppers moved freely between plants within a cage. The cages were randomly paired on a table into six blocks; each block had two cages, one with and one without planthoppers, and inside the cage there was a representative for each cordgrass population. After two planthopper generations ( $21 \mathrm{wk}$ ) we measured the plant traits: shoot length, shoot number, leaf number, and aboveground biomass (dried). For each block, before statistical analysis we calculated the ratio of the value of the plant trait with insects to the value of the plant trait without insects. The data were analyzed by twoway ANOVA with block and cordgrass population as main effects. The comparison of interest to our a priori hypothesis was that native $S$. alterniflora from Virginia should be more tolerant than cordgrass of other origins. The a priori comparisons were performed using absolute measurements for each variable. Data from experiment E (see below) were also used in tests of tolerance.

\section{Intrapopulation variation}

We compared the range and $\mathrm{CV}$ within populations between the two contact histories. To create the treat- 


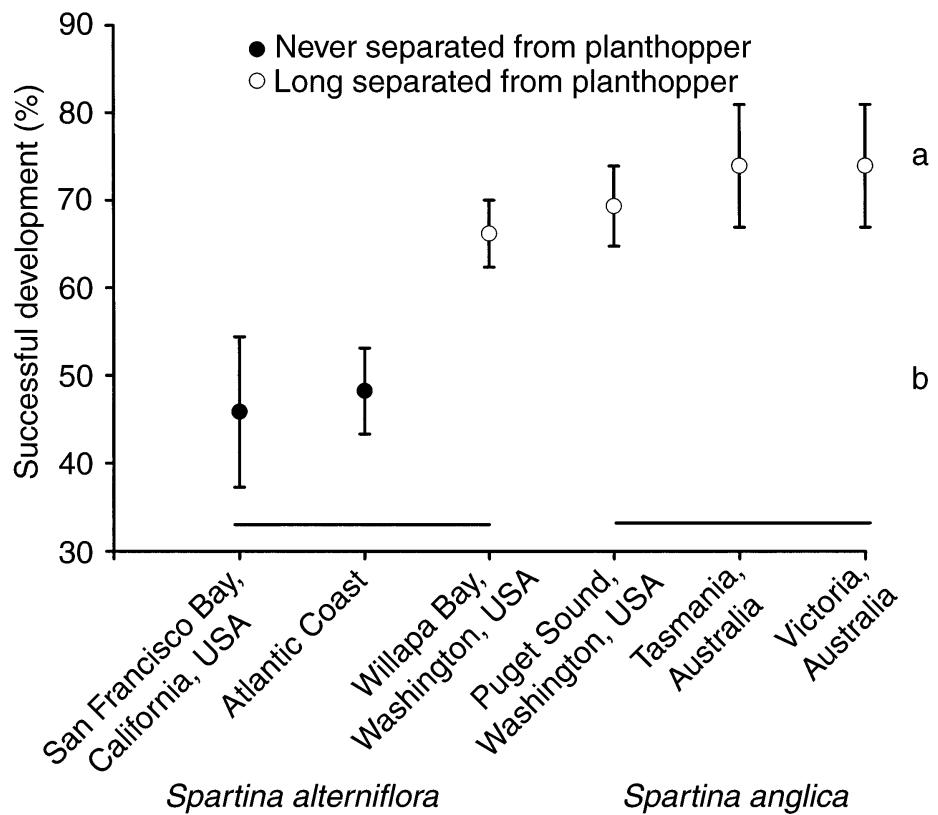

FIG. 1. Development of Prokelisia marginata nymphs to adults during a 12-d experimental period, as a function of contact history. By a priori contrast, development on the cordgrass that has never grown apart from the planthopper (b) was lower than on cordgrasses that had grown apart from the herbivore for many generations (a). See Results for statistics. All experiments were conducted in the greenhouse at the Bodega Marine Laboratory, Bodega Bay, California, USA. ments (experiment $\mathrm{E}$ ), we covered the plant in each pot with a translucent cylindrical sock $(20 \mathrm{~cm}$ diameter $\times$ $1 \mathrm{~m}$ tall) of spin-bonded polyester (American Agrofabrics, $18.6 \mathrm{~g} / \mathrm{m}^{2}$; McConkey, Summer, Washington, USA). At the beginning of the experiment, five male and five female adult planthoppers $(\sim 0.66$ planthoppers/cm of shoot) were added to each sock (plant, replicate, pot) of the high density treatment; no planthoppers were intentionally added to the very low density treatment. However, during the experiment a few planthoppers $(<1$ insect per week per sock) gained entry and were removed monthly from the very low density treatment. The very low density treatment was important to test the notion that disease transmitted by the planthopper was the cause of the previously observed harm done to the plant by this herbivore (Davis et al. 2002). Treatment combinations were randomized in position on greenhouse tables. We performed a two-way ANOVA with main effects of cordgrass population origin and planthopper density and the interaction of these two main effects. Dependent variables were log planthopper density (number of insects per centimeter of shoot) that grew over this 20-wk experiment, shoot survival, number of living shoots, length of living shoots, biomass above ground, and plant mortality rate. For comparison of contact histories (the first and second objectives of this study) we tested the interaction between cordgrass origin and planthopper density; this tests differences between the provenances in resistance to and tolerance of the planthopper.

\section{Results}

\section{Suitability of host plants for insects}

Resistance to Prokelisia marginata was greater in cordgrass populations that have been consistently ex- posed to it than in those populations that have been separated from this herbivore for many generations. Successful development of second instar nymphs to adults (experiment A) was higher on plants with a long history of no contact with the insect $(72 \%)$ than plants with a continuous history of contact $(50 \%$, test of a priori hypothesis, $t=8.0$, df $=4, P=0.0013$, Fig. 1). Nymphal developmental success on the seven native populations of $S$. alterniflora from the Atlantic coast was $53 \%$ and was $46 \%$ from San Francisco Bay (not separated from the planthopper). This was in contrast to provenances with opposite plant-insect contact history; development on Willapa Bay S. alterniflora was $71 \%$, on $S$. anglica from Puget Sound it was $69 \%$, Tasmania 74\%, and Victoria, Australia 74\%. Mortality of the planthoppers did not differ by plant-insect contact history $(22 \%$ on long-separated provenances, $22.4 \%$ on never-separated natives, $t=0.1$, df $=4, P$ $=0.92$ ), the distinction was due to developmental rate rather than survival.

The rate of nymphal emergence (experiment B) was twice as high on cordgrasses from populations separated from the planthopper for many generations than on the cordgrasses from populations with the opposite plant-insect contact history. On Willapa Bay S. alterniflora, 9.7 nymphs emerged per each founding malefemale pair, significantly higher than the 4.6 nymphs emerging per male-female pair on cordgrasses from Virginia $(t=3.7$, df $=71, P<0.001$, based on logtransformed data). Oviposition rates over $30 \mathrm{~d}$ (experiment C) did not differ as a function of contact history; female planthoppers laid on average 31.2 eggs $(t=1.9$, df $=6, P=0.11)$ on plants from Willapa Bay and San Francisco Bay cordgrass. 


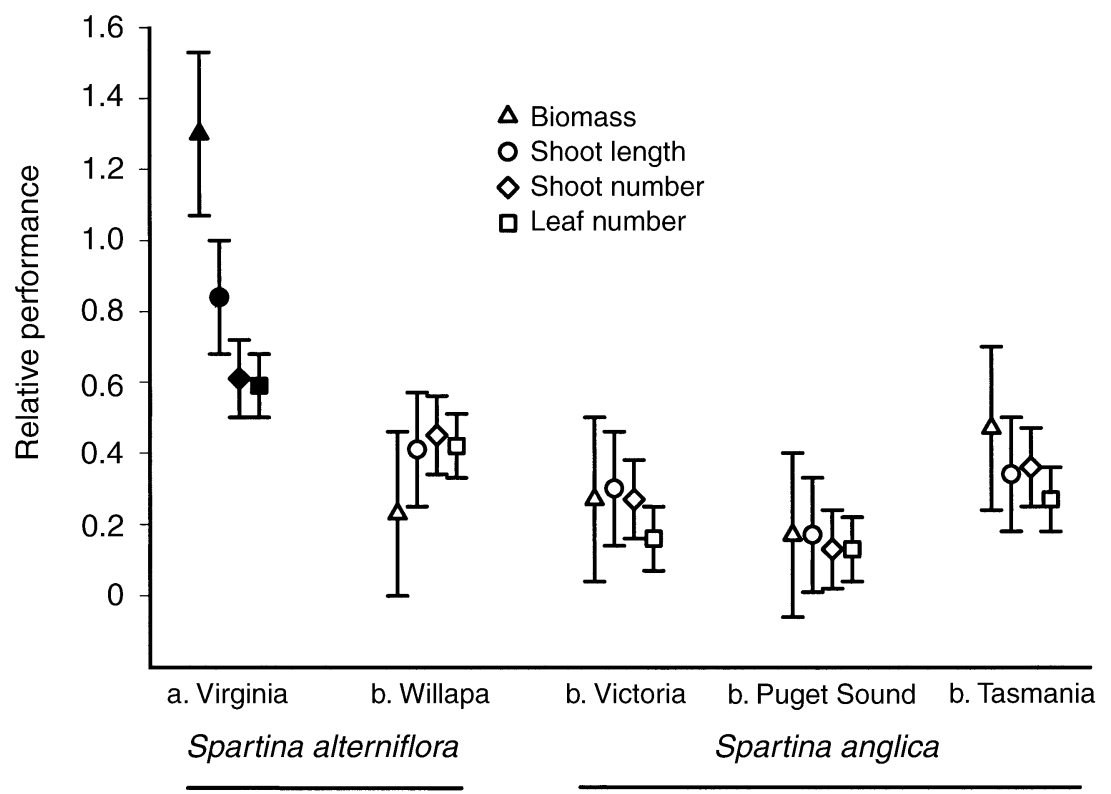

FIG. 2. Relative performance of cordgrass measured as a ratio of the value of the trait for plants grown with Prokelisia marginata over that for plants growing without the planthopper, as a function of contact history. By a priori contrast, native cordgrass ("b" populations) from Virginia suffered less from herbivory in all four plant traits than did cordgrasses that had been separated from the planthopper for many generations ("a" populations). See Results for statistics.

\section{Ability to withstand herbivory}

The relative tolerance of Prokelisia marginata was greater in cordgrass populations of long-standing associations with the planthopper than in those that have been long-separated from it. Native Spartina alterniflora from Virginia performed better with the herbivore (relative to without it) than did the Willapa population of $S$. alterniflora and those of $S$. anglica (experiment D, Fig. 2). The advantage of the Virginia provenance was greatest for biomass $\left(F_{4,20}=4.4 ; P=0.01\right)$ and leaf number $\left(F_{4,20}=4.9 ; P=0.006\right)$, but advantage over long-separated provenances was also substantial for shoot number $\left(F_{4,20}=2.5 ; P=0.07\right)$ and shoot length $\left(F_{4,20}=2.6 ; P=0.07\right)$. While the mean effect on biomass in the Virginia population was statistically nil, it reduced shoot length 1.2-fold, shoot number 1.6fold, and leaf number 1.7-fold in this native population of cordgrass (Fig. 2). The reductions caused by the herbivore in all traits were much greater in provenances with the contrasting contact history, ranging from reduction of 2.2-fold for shoot number in Willapa Bay S. alterniflora to a 7.7-fold reduction in shoot number and leaf number for $S$. anglica from Puget Sound.

Mortality due to the planthopper paralleled the results for the other measures of tolerance. No plants died in the without-planthopper treatment for any population of either contact history. In the with-planthopper treatment, mortality was zero for Virginia $S$. alterniflora; $25 \%$ for Willapa Bay S. alterniflora; $43 \%$ for Australia S. anglica, $50 \%$ for Puget Sound S. anglica, and $50 \%$ for Tasmania S. anglica (test of a priori hypothesis of lower mortality in the long-standing cordgrass-planthopper associations, Kruskal-Wallis test, $\chi^{2}=7.4$, df $\left.=1, P=0.006\right)$.

\section{Planthopper population growth}

Planthopper population growth rate is a parameter that measures the combined effects of resistance and tolerance. In the experiments, just as in nature, densities grew to levels that caused distinct chlorosis, curled and dead leaves, and stunting (hopper burn), which is plant damage with potential to affect population growth of the herbivore. We performed two experiments (D and E) with this metric. In both, population growth was faster upon plants that came from populations separated from the planthopper for many generations than on plants with continuous plant-insect contact history. Experiment D was begun at 0.5 planthoppers/cm of stem. Densities grew to 1.9 planthoppers/cm of stem on the native Virginia S. alterniflora and to a mean of 4.7 planthoppers/cm of shoot on provenances of the long-separated cordgrasses, over one generation $(10 \mathrm{wk})$ of the planthopper $(t=2.25$, df $=$ $38, P<0.03)$. Breaking down the long-separated provenances, final density was 3.1 planthoppers/cm of stem on S. alterniflora from Willapa Bay, and on the $S$. anglica, 4.7 planthoppers/cm of stem from Australia, 9.3 planthoppers/cm of stem from Puget Sound, and 2.6 planthoppers/cm of stem from Tasmania.

\section{Intrapopulation variation}

The S. alterniflora from Willapa Bay, which has been separated from the planthopper for $\sim 100$ years, had much higher variation among genotypes in population 


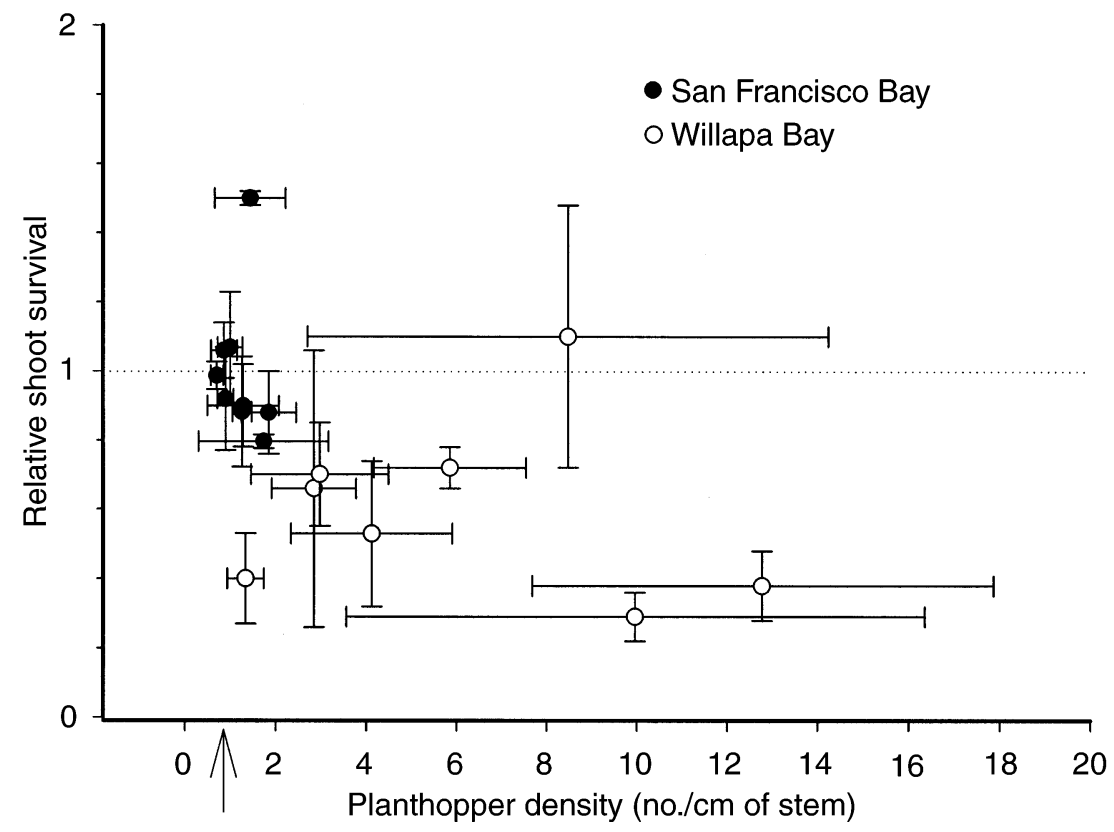

FIG. 3. Variation among genotypes in population growth rate of Prokelisia marginata and in shoot death caused by this herbivore to Spartina alterniflora from Willapa Bay, which has been separated from the planthopper for $\sim 100$ years, and to $S$. alterniflora from San Francisco Bay, which has never been separated from the planthopper (means $\pm 1 \mathrm{SE}$ ). The arrow indicates the density of 0.66 planthoppers/cm of shoot at the beginning of this 20 -wk experiment. The point in the upper right represents a genotype from Willapa Bay that was virtually unaffected by the third highest planthopper density of the 17 plant genotypes in the experiment; it lacked resistance to the planthopper and simultaneously was quite tolerant of it.

growth rate of the herbivore, and in harm caused by it, than that from San Francisco Bay (never separated). The plant genotypes from Willapa Bay supported a wide range of densities, 1.3-12.8 planthoppers/cm of stem (mean 11.5); it was $\sim 10$-fold wider than the range for genotypes from San Francisco Bay (0.7-1.9 planthoppers/cm of stem, experiment E; abscissa, Fig. 3). The worst plant genotype for planthoppers from Willapa Bay was quite close to the mean from San Francisco Bay. At the same time, most genotypes from Willapa Bay supported planthopper densities 2-7-fold greater than any from San Francisco Bay. Seven of eight Willapa Bay genotypes had mean densities greater than the highest planthopper density on San Francisco Bay genotypes. Mean differences in planthopper density between cordgrasses of contrasting contact history were consistent with other results in this study. During this experiment, the accession mean increased from $\sim 0.7$ to 4.6 planthoppers/cm of shoot on Willapa Bay plants, but from 0.7 to only 1.3 planthoppers on those from San Francisco Bay $(t=5.1$, df $=15, P=$ $0.0001)$. Nevertheless, the coefficient of variation of planthopper density among genotypes was not different between Willapa Bay (37.0\%) and San Francisco Bay (33.5\%, $P>0.7$, by $F$ test; Zar 1984).

The range of relative shoot survival (survival with the planthopper/survival without it) was much higher among Willapa Bay genotypes (range $=0.72$, from 0.3 to 1.1 ; overall mean survival $=0.6, \mathrm{SE}=0.09$ ) than among those from San Francisco Bay (range $=0.6$, from 0.8 to 1.5 , overall mean survival $=1.0$ ) of $S$. alterniflora (ordinate, Fig. 3). Planthoppers killed more than half of shoots of three of eight genotypes from Willapa Bay, while they killed no shoots in one other from the same population. In contrast, they killed no more than $20 \%$ of shoots of any San Francisco genotype. The coefficient of variation in relative shoot survival among genotypes was greater for Willapa Bay $(44.9 \%)$ than for San Francisco Bay $(20.8 \%, P<0.05$ by $F$ test; Zar 1984). Plant mortality paralleled the pattern of greater variation among genotypes from Willapa Bay than from San Francisco Bay. The planthoppers killed $\sim 35 \%$ of plants of some Willapa Bay genotypes and none of others $\left(\chi^{2}=14.6\right.$, df $=1, P<$ $0.0001)$, while they killed very few plants for any genotype from San Francisco Bay $\left(\chi^{2}=4.1\right.$, df $=1, P$ $<0.5)$. The interaction term of cordgrass population origin by planthopper density in the two-way ANOVA (the first and second objectives of the study) was statistically significant for shoot survival $\left(F_{1,15}=13.42\right.$; $P=0.001)$.

Finally, as another test of tolerance, mean differences in shoot survival between these cordgrasses of contrasting contact history were consistent with other results in this study. All but one Willapa Bay genotype had lower survival of shoots than any genotype from San Francisco Bay. The only morphological feature to differ between cordgrass populations in the low plant- 
hopper density treatment was "shoots per plant" (mean, Willapa Bay 18.2 shoots per plant, San Francisco Bay 11.4 shoots per plant; $F_{1,15}=6.05, P=$ $0.019)$. It is noteworthy that cordgrasses of both provenances were vigorous in the very low density treatment. Thus, we found no evidence that diseases transmitted by the planthopper, such as phytoplasma, were the cause of harm to cordgrasses by this insect (Davis et al. 2002).

A concave pattern of decreasing shoot survival with increasing planthopper density is apparent in Fig. 3, with highest survival and lowest planthopper density described by a tight cluster of genotypes from San Francisco Bay. Genotypes from Willapa Bay account for most this relationship. Perhaps the most interesting genotype of the study was the uppermost point in Fig. 3 , which departs conspicuously from the rough negative correlation between tolerance and the densities of planthopper colonies that developed during this long experiment. While other genotypes from Willapa Bay were harmed by even quite low densities of the planthopper, this unusual genotype was virtually unaffected by the third highest density ( 8.5 planthoppers $/ \mathrm{cm}$ of stem) of the 17 genotypes in the experiment. Thus, this Willapa Bay genotype lacked resistance to the planthopper, while being quite tolerant of it.

\section{DISCUSSION}

We found that within-population variation in traits related to tolerance was greater among genotypes of Spartina alterniflora in a population that had long been separated from the planthopper than in a population that had never been separated from it. Both shoot and plant mortality showed this pattern, as did population growth of the planthopper. These results are summarized by the relationship between cordgrass shoot survival and planthopper population growth (Fig. 3). There was little variation in this relationship among San Francisco Bay genotypes, none of which suffered greatly from the low densities of planthopper developing over the 20-wk experiment, which is consistent with previous findings (Daehler and Strong 1995). In contrast, there was huge variation among genotypes of the estranged population in both shoot survival and planthopper population growth. All but one Willapa Bay genotype suffered more than any San Francisco Bay genotype. Even at fairly low planthopper population densities, the harm done to most genotypes of the estranged cordgrass population was substantial.

Most pertinent to biological control, and inspiring the title of this paper, was the Willapa Bay genotype at the other extreme, which was virtually unaffected by the moderately high densities of the planthopper developing during the experiment. Thus, this genotype lacked resistance but was tolerant of the planthopper. Genotypes with this combination of traits could be insidious to biological control. Initially, such genotypes could accelerate control by producing many herbivores to harm the other, vulnerable plant genotypes. However, the longer-term outcome would be erosion of biological control, as the frequency of tolerant, nonresistant genotypes increased due to the selection pressure imposed by the biological control agent.

Extending previous findings (Daehler and Strong 1997, Wu et al. 1999), we also showed that the invasive cordgrasses Spartina alterniflora and S. anglica, which have been long-separated from the specialist planthopper for many generations, are on average more vulnerable to this herbivore than native cordgrasses populations never separated from it. Resistance, tolerance, and herbivore population growth (a combination of resistance and tolerance) all varied in this manner as a function of cordgrass-planthopper contact history. All comparisons in all traits investigated (three insect traits, five plant traits) showed that the six invasive cordgrass populations that have been estranged from the insect were more vulnerable than the six native cordgrass populations. The relative shoot survival of one genotype from San Francisco was $>1$, which would indicate that the planthopper somehow caused an increase in shoot survival of this genotype. We have observed other genotypes of S. alterniflora from Virginia to have higher biomass when supporting low densities of moderate densities of $P$. marginata (Daehler and Strong 1997; D. Garcia-Rossi, personal observation). The meaning of this effect is unclear, and more research is necessary to determine whether low densities of the planthopper can actually stimulate net growth. One idea is that the planthopper stimulates transfer of resources from the root to the shoot and that this effect varies among genotypes. It is possible that this is a manifestation of "overcompensation to herbivores" (Paige 1994).

Genetic variation in vulnerability to natural enemies is germane to the practice and science of biological control. Hundreds of pests have been controlled biologically, some for long periods of time, throughout a huge range of environmental conditions from the tropics to high latitudes (Waage and Greathead 1988, Julien 1992). The selection imposed by enemies can be substantial (Gould et al. 1997), and the unusual simplicity of food webs in biological control (Hawkins et al. 1999) should magnify selection due to enemies (Holt and Hochberg 1997). At the same time, while evolved resistance to chemical control is a widespread and serious practical issue in management of pests (Georghiou 1988), examples of evolutionary erosion of biological control are very few and almost restricted to insect pests (Muldrew 1953, Fenner 1983, Young 1986).

While the evolution of weed resistance and tolerance as a result of selection by herbivore biological control agents is a fascinating topic in evolutionary ecology (Holt and Hochberg 1997), it is virtually absent from the literature on biological control. Our results provide a clear example of the potential for this scenario, with the interesting twist of extra-evolutionary dynamics 
caused by high variance in vulnerability of the weed. Such variance could come about as a result of relaxed selection in the enemy-free environment in which invasive species find themselves (Colosi and Schaal 1992, Thompson 1998).

In Willapa Bay, S. alterniflora has spread over $\sim 6000$ ha of previously open intertidal habitat during the 20th century, which amounts to $\sim 30 \%$ of the 19000 ha of intertidal lands that are suitable for colonization by this plant. The invasion degrades the habitat of migratory shorebirds, waterfowl, fish, benthic invertebrates, and commercially harvested clams and oysters (Anonymous 1993, 1997). The Washington Legislature declared this invasion "an environmental disaster" in 1995 (RCW 17.26.005), and since that time state and federal agencies have spent approximately $\$ 3$ million (US) on this problem. In summer of 2000, P. marginata from San Francisco Bay was introduced to Willapa Bay under permit of the Washington Department of Agriculture with unanimous approval of The Technical Advisory Group on Biocontrol of Weeds, of the U.S. Department of Agriculture, Animal and Plant Health Inspection Service (APHIS). The introduction of this insect was made only after extensive host-specificity testing and disease screening (Davis et al. 2002, Grevstad et al. 2003).

Why are our results interesting for the specific case of biological control of $S$. alterniflora by $P$. marginata in Willapa Bay? In the event that planthopper densities grow high enough, the first result will be lessened growth, reduced fertility, and even mortality of the most abundant cordgrass genotypes (those resembling the open points on the lower half of Fig. 3). This would appear to be a success for the biological control of $S$. alterniflora in Willapa Bay. However, it is possible that natural selection favoring genotypes tolerant of the planthopper would erode the effectiveness of biological control. In this scenario, other measures such as mechanical or chemical control (Patten 2002) would be necessary to prevent selection for cordgrass genotypes that are impervious to the agent. One could advocate the choice of agents with impact so severe that no host genotypes survive (extremely high virulence), but such agents are unknown in the specific case under discussion and not very frequent in cases of weed control (Kennedy et al. 1987, Julien 1992).

One case similar, but not identical, to ours is known (Burdon et al. 1981). Three forms of rush skeletonweed, Chondrilla juncea, were introduced into Australia. Two introduced biological control agents, the fungus Puccinia chondrillina and the eriophorid mite Aceria chondrillae, attack one of the three forms preferentially to the other forms. In less than a decade after introduction of the control agents, the geographical distribution of the attacked form of rush skeletonweed decreased greatly, while that of the other two forms, which compete with the attacked form, increased concomitantly. While the inheritance of resistance and rel- ative tolerance of $S$. alterniflora to $P$. marginata are unknown, it is not unreasonable to assume that the dynamics could proceed in an analogous way to the Australian case cited above.

\section{ACKNOWLEDGMENTS}

This research was supported by NOAA, University of Washington Sea Grant \#NA86RG0585 to D. R. Strong, A. Hastings, and M. Wecker and NSF Grant \#0083583 to A. M. Hastings, T. Grosholz, and D. R. Strong. We thank C. Anttila, D. Ayres, K. Zaremba, J. Levy, and H. Davis for aid in the field and laboratory and to P. Hedge, M. Bertness, C. Anttila, and S. Pennings for plant collections.

\section{Literature Cited}

Anonymous. 1993. Noxious emergent plant management environmental impact statement (EIS). Washington State Department of Natural Resources, Olympia, Washington, USA.

Anonymous. 1997. Control of smooth cordgrass (Spartina alterniflora) on Willapa National Wildlife Refuge, environmental assessment. United States Fish and Wildlife Department, Willapa National Wildlife Refuge, Ilwaco, Washington, USA.

Ayres, D. R., D. Garcia-Rossi, H. G. Davis, and D. R. Strong. 1999. Extent and degree of hybridization between exotic (Spartina alterniflora) and native (S. foliosa) cordgrass (Poaceae) in California, USA determined by random amplified polymorphic DNA (RAPDs). Molecular Ecology 8:11791186.

Barrett, S. C. H. 1992. Genetics of weed invasions. Pages 70-91 in S. K. Jain and L. W. Botsford, editors. Applied population biology. Kluwer Academic, Boston, Massachusetts, USA.

Burdon, J. J., R. H. Groves, and J. M. Cullen. 1981. The impact of biological control on the distribution and abundance of Chondrilla juncea in south-eastern Australia. Journal of Applied Ecology 18:957-966.

Clement, S. L. 1994. Resistance among populations of yellow starthistle to thistle-head insects: results from garden plots in Italy. Biological Control 4:149-156.

Colosi, J. C., and B. A. Schaal. 1992. Genetic variation in wild proso millet. Proceedings of the North Central Weed Science Society 47:21-22.

Daehler, C. C. 1999. Inbreeding depression in smooth cordgrass (Spartina alterniflora, Poaceae) invading San Francisco Bay. American Journal of Botany 86:131-139.

Daehler, C. C., and D. R. Strong. 1995. Impact of high herbivore densities on introduced smooth cordgrass, Spartina alterniflora, invading San Francisco, Bay, California. Estuaries 18:409-417.

Daehler, C. C., and D. R. Strong. 1996. Status, prediction and prevention of introduced cordgrass Spartina spp. invasions in Pacific estuaries, USA. Biological Conservation 78:51-58.

Daehler, C. C., and D. R. Strong. 1997. Reduced herbivore resistance in introduced smooth cordgrass (Spartina alterniflora) after a century of herbivore-free growth. Oecologia (Berlin) 110:99-108.

Davis, H. G., D. Garcia-Rossi, M. Daoust, and D. R. Strong. 2002. The use of molecular assays to identify plant pathogenic organisms vectored by biological control agents. BioControl 47:487-497.

Denno, R. F., G. K. Roderick, M. A. Peterson, A. F. Huberty, H. G. Dobel, M. D. Eubanks, J. E. Losey, and G. A. Langellotto. 1996. Habitat persistence underlies intraspecific variation in the dispersal strategies of planthoppers. Ecological Monographs 66:389-408.

Faber, P. 2002. Grass wars: good intentions gone awry. Coast and Oceans 16:24-26. 
Fenner, F. 1983. Biological control, as exemplified by smallpox eradication and mixomatosis. Proceedings of the Royal Society of London B 218:259-285.

Gagné, R. J. 1981. A new species of North American Cecidomyiidae (Diptera) from Spartina alterniflora (Poaceae). Proceedings of the Entomological Society of Washington 83: $129-132$.

Georghiou, G. P. 1988. An overview of insecticide resistance. Abstracts of papers. American Chemical Society 196: AGRO 35.

Gould, F., A. Anderson, A. Jones, D. Sumerford, D. G. Heckel, J. Lopez, S. Micinski, R. Leonard, and M. Laster. 1997. Initial frequency of alleles for resistance to Bacillus thuringiensis toxins in field populations of Heliothis virescens. Proceedings of the National Academy of Sciences of the United States of America 94:3519-3523.

Grevstad, F., D. R. Strong, D. Garcia-Rossi, R. Switzer, and M. Wecker. 2003. Biological control of Spartina alterniflora in Willapa Bay, Washington: agent specificity, introduction, and early results. Biological Control 27:32-42.

Hawkins, B. A., N. J. Mills, M. A. Jervis, and P. W. Price. 1999. Is the biological control of insects a natural phenomenon? Oikos 86:493-506.

Heady, S. E., and S. W. Wilson. 1990. The planthopper genus Prokelisia (Homoptera: Delphacidae): morphology of female genitalia and copulatory behavior. Journal of the Kansas Entomological Society 63:267-278.

Holt, R. D., and M. H. Hochberg. 1997. When is biological control evolutionarily stable (or is it)? Ecology 78:267278.

Julien, M. H. 1992. Biological control of weeds. A world catalogue of agents and their target weeds. Third edition. CAB International, Wallingford, UK.

Keane, R. M., and M. J. Crawley. 2002. Exotic plant invasions and the enemy release hypothesis. Trends in Ecology and Evolution 17:164-170.

Kennedy, G. G., F. Gould, O. M. B. Deponti, and R. E. Stinner. 1987. Ecological, agricultural, genetic, and commercial considerations in the deployment of insect-resistant germplasm. Environmental Entomology 16:327-338.

Liu, T.-X., and J. O. Howell. 1994. A new species of Haliaspis from Texas, USA (Homoptera: Coccoidea: Diaspididae). Journal of Entomological Science 29:134-140.
McEvoy, P. B. 1996. Host specificity and biological pest control. Bioscience 46:401-405.

Muldrew, J. A. 1953. The natural immunity of the larch sawfly Pristiphora erichsonii [Hartung] to the introduced parasite Mesoleius tenthredinis [Morely] in Manitoba and Saskatchewan. Canadian Journal of Zoology 31:313-332.

Paige, K. N. 1994. Herbivory and Ipomopsis aggregata: differences in response, differences in experimental protocol, a reply to Bergelson and Crawley. American Naturalist 143: 739-749.

Patten, K. 2002. Smooth cordgrass (Spartina alerniflora) control with Imazapr. Weed Technology 16:826-832.

Raybould, A. F. 1991. The evolution of Spartina anglica C.E. Hubbard (Gramineae): origin and genetic variability. Biological Journal of the Linnean Society 43:111-126.

Strauss, S. Y., and A. A. Agrawal. 1999. The ecology and evolution of plant tolerance to herbivory. Trends in Ecology and Evolution 14:179-185.

Strong, D. R., J. H. Lawton, and R. Southwood. 1984. Insects on plants: community patterns and mechanisms. Harvard University Press, Cambridge, Massachusetts, USA.

Strong, D. R., and R. W. Pemberton. 2000. Biological control of invading species: risk and reform. Science (Washington, D.C.) 288:1969-1970.

Thompson, J. N. 1998. Rapid evolution as an ecological process. Trends in Ecology and Evolution 13:329-332.

Vermeij, G. J. 1996. An agenda for invasion biology. Biological Conservation 78:3-9.

Waage, J. K., and D. J. Greathead. 1988. Biological control challenges and opportunities. Philosophical Transactions of the Royal Society of London B, Biological Sciences 318: 111-128.

Walling, L. L. 2000. The myriad plant responses to herbivores. Journal of Plant Growth Regulation 19:195-216.

Wu, M.-Y., S. Hacker, D. Ayres, and D. R. Strong. 1999 Potential of Prokelisia spp. as biological control agents of English cordgrass, Spartina anglica. Biological Control 16: 267-273.

Young, E. C. 1986. The rhinoceros beetle project: history and review of the research programs. Agricultural Ecosystems and Environments 15:149-166.

Zar, J. H. 1984. Biostatistical analysis. Second edition. Prentice-Hall, New York, New York, USA. 